\title{
Authors in this issue of the Nicholai Studies
}

Milan Kostrešević studied theology, archeology and philosophy and completed his Masters in Orthodox theology at the University of Belgrade in 2011. Since 2013 he has been a doctoral candidate and assistant at the Department of Old Catholic Theology at the University of Bern, and at New Testament Department at the Institute for Biblical Studies. He is also a president of the Working Group of Christian Churches in Switzerland (agck.ch). ORCID iD: https://orcid.org/o0oo-0002-6356-5944.

Nicolas Mabin is a subdeacon at the London Cathedral parish of the Russian Orthodox Church Outside Russia. He has a degree in theology (B.A. Hons) from the University of Kent at Canterbury, UK, and the degree of Diploma in Orthodox Theological Studies, awarded by the Center for Traditionalist Studies, Etna, USA.

Vladimir Cvetković is a research associate professor at the Institute of Philosophy and Social Theory of the University of Belgrade. Cvetković obtained his $\mathrm{BA}$ and $\mathrm{PhD}$ in Philosophy from the University of Belgrade in 1997 and 2007 respectively. He has also been awarded a MA by thesis in Theology from Durham University in 2002. He has hold research and teaching positions at the universities of Aarhus (Denmark), St Andrews (Scotland, UK), Oslo (Norway) and Niš (Serbia). His research interests include Patristics, Ancient and Byzantine Philosophy and Modern Orthodox Theology. ORCID iD: https://orcid.org/oooo-00o1-9608-9537.

Zdenko Š. Širka is a Lutheran ecumenical theologian, engaged as a researcher and teacher at the Ecumenical Institute of the Protestant Theological Faculty of Charles University (Prague, Czech Republic). After 
finishing his master studies in theology in Bratislava (Slovakia), he continued his education at the Hermeneutical Institute of the University of Tübingen (2004-2006) and engaged several study leaves and trainings at the universities in Salzburg, Münster, Belgrade, Vienna, Leuven, Sofia, Paris and Heidelberg. Širka finished his doctoral studies in ecumenical theology at the Protestant Theological Faculty of Charles University. He is the author of Transcendence and Understanding: Gadamer and Modern Orthodox Hermeneutics in Dialogue (Eugene, OR, 2020); his research interests are Hermeneutics, Modern Orthodox Theology, Patristics, Philosophy. ORCID iD: https://orcid.org/oooo-0002-1573-3800.

Srećko Petrović is a postgraduate student at the University of Belgrade. He graduated from the Faculty of Orthodox Theology of the University of Belgrade. He received his MAS in Ecumenical Studies from the Bossey Ecumenical Institute at the University of Geneva in 2019. His research interests include Patristics, History of Christianity, Modern Orthodox Theology, Ecumenical Theology, and History of the Ecumenical Movement. ORCID iD: https://orcid.org/oooo-0002-4916-6242. 